6 - ORIGINAL ARTICLE

Experimental Urology

\title{
Effect of sildenafil in renal ischemia/reperfusion injury in rats ${ }^{1}$
}

\author{
Efeito do sildenafil na lesão renal por isquemia/reperfusão em ratos
}

\author{
Paulo José de Medeiros', Arthur Villarim Neto"I Francisco Pignataro Lima ${ }^{\mathrm{II}}$, Ítalo Medeiros Azevedo ${ }^{\mathrm{IV}}$, Layra Ribeiro de Sousa \\ Leãov ${ }^{\mathrm{V}}$, Aldo Cunha Medeiros ${ }^{\mathrm{VI}}$
}

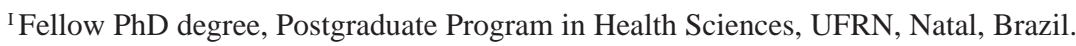

II PhD, Associate Professor, Department of Physiology, UFRN, Natal, Brazil.

${ }^{\text {III }} \mathrm{PhD}$, Associate Professor, Department of Pathology, UFRN, Natal, Brazil.

Iv Statistician, Department of Surgery, UFRN, Natal, Brazil.

${ }^{\mathrm{v}}$ Graduate Student, Scientific Initiation Program, UFRN, Natal, Brazil.

${ }^{\mathrm{VI}}$ Chairman, Full Professor, Department of Surgery, UFRN, Natal, Brazil.

\begin{abstract}
Purpose: To evaluate the effect of sildenafil, administered prior to renal ischemia/reperfusion (I/R), by scintigraphy and histopathological evaluation in rats. Methods: Twenty-four rats were divided randomly into two groups. They received 0.1 ml of 99mTechnetium-etilenodicisteine intravenous, and a baseline (initial) renal scintigraphy was performed. The rats underwent 60 minutes of ischemia by left renal artery clamping. The right kidney was not manipulated. The sildenafil group ( $\mathrm{n}=12$ ) received orally $1 \mathrm{mg} / \mathrm{kg}$ of sildenafil suspension 60 minutes before ischemia. Treatment with saline $0.9 \%$ in the control group ( $\mathrm{n}=12$ ). Half of the rats was assessed after 24 hours and half after seven days I/R, with new renal scintigraphy to study differential function. After euthanasia, kidneys were removed and subjected to histopathological examination. For statistical evaluation, Student t and Mann-Whitney tests were used. Results: In the control group rats, the left kidneys had significant functional deficit, seven days after I/R, whose scintigraphic pattern was consistent with acute tubular necrosis, compared with the initial scintigraphy $(\mathrm{p}<0.05)$. Sildenafil treatment resulted in better differential function of the left kidneys 24h after reperfusion, compared with controls. Histopathologically, the left kidney of control rats (24 hours after I/R) showed a higher degree of cellular necrosis when compared with the sildenafil treated rats ( $<<0.05$ ). Conclusion: Sildenafil had a protective effect in rat kidneys subjected to normothermic I/R, demonstrated by scintigraphy and histomorphometry.
\end{abstract}

Key words: Ischemia. Reperfusion. Kidney. Radionuclide Imaging. Technetium Tc 99m Mertiatide. Rats.

\section{RESUMO}

Objetivo: Estudar o efeito do sildenafil, administrado previamente à isquemia/reperfusão (I/R) renal, em avaliações cintilográficas e histopatológicas em ratos. Métodos: Vinte e quatro ratos Wistar foram aleatoriamente distribuídos em dois grupos. Os animais receberam 0,1 ml IV de 99mTecnécio-Etilenodicisteína, foram submetidos à cintilografia renal inicial e em seguida submetidos a isquemia no rim esquerdo, com oclusão da artéria renal, durante 60 minutos, com posterior reperfusão. O grupo sildenafil (n=12) recebeu previamente $1 \mathrm{mg} / \mathrm{kg}$ de sildenafil em suspensão 60 minutos antes da isquemia. Solução salina 0,9\% foi administrada no grupo controle (n=12). Metade dos animais de cada grupo foi avaliada após 24 horas e a outra metade após sete dias de reperfusão, com nova cintilografia renal. Após eutanásia, os rins foram retirados e submetidos a exame histopatológico. Na avaliação estatística foram empregados os testes t de Student e de Mann-Whitney. Resultados: Foi observado no rim esquerdo (submetido a I/R) do grupo controle déficit funcional diferencial nas imagens cintilográficas após sete dias, com padrão de necrose tubular aguda, quando comparado com a cintilografia inicial (p<0,05). O tratamento com sildenafil resultou em melhor função diferencial do rim esquerdo 24h após reperfusão, comparado com os controles. Na histopatologia, os rins esquerdos dos animais do grupo controle (24 horas pós-I/R), apresentaram maior grau de necrose celular quando comparados com o grupo tratado com o sildenafil $(\mathrm{p}<0,05)$. Conclusão: $O$ sildenafil teve efeito protetor em rins de ratos submetidos à isquemia/reperfusão normotérmica, demonstrado por cintilografia e histomorfometria.

Descritores: Isquemia. Reperfusão. Rim. Cintilografia. Tecnécio Tc 99m Mertiatida. Ratos.

${ }^{1}$ Research performed at the Department of Surgery, School of Medicine, Federal University of Rio Grande do Norte (UFRN), Natal, Brazil. 


\section{Introduction}

The renal injury caused by the ischemia/reperfusion (I/R) occurs inevitably in surgical procedures in which the kidneys remain without blood supply for some time. This is observed during kidney transplantation, vascular surgery of aorta and renal arteries and in partial nephrectomy. In kidney transplantation, the graft dysfunction, acute rejection and chronic kidney disease correlate with the degree of ischemic injury and increases with the presence of normothermic ischemia, specially when the organs are from donors with cardiac arrest ${ }^{1}$. In the partial nephrectomy, although the goal is to preserve renal function, the I/R injury often occurs in the remaining renal parenchyma due to clamping of the renal artery, carried out in order to prevent bleeding and to allow adequate visualization of organs and tissues ${ }^{2,3}$.

Endothelial injury causes changes in the vascular responses to vasoactive substances ${ }^{4}$. Aiming to protect the organs against the effects of $I / R$, several substances have been used in experimental studies, many of them related to the performance of the nitric oxide $(\mathrm{NO})^{6}$. In the last two decades, attention has turned to sildenafil, an inhibitor of phosphodiesterase-5, that increases the concentration of guanosine 3,5-cyclic monophosphate (cGMP), resulting in arterial vasodilation. The use of this substance was protective against endothelial dysfunction in transplanted heart, and a hemodynamic improvement in auto-transplanted kidneys has been showed in animals preconditioned with sildenafil ${ }^{7,8}$. The aim of this study was to analyse whether previous administration of sildenafil has renoprotective effect on the episode of I/R in rats, based on renal scintigraphic and histopathological examination.

\section{Methods}

Wistar rats weighing $268 \pm 15 \mathrm{~g}$ were obtained from the Center for Health Sciences, UFRN, Brazil. The animals were housed in polypropilene cages and received standard rat chow (Labina ${ }^{\circledR}$ Purina) and water ad libitum. After 7 days of acclimatization at the laboratory, prior to surgery the rats were fasted overnight in separate cages. The investigational protocol was approved by the Institutional Animal Care Committee, and the research was performed in accordance with the guidelines of the Brazilian legislation for scientific use of animals (Law $n^{0} 11.794 / 08$ ).

Twenty four rats were randomly assigned to a control group-CG $(n=12)$, and sildenafil group-SG $(n=12)$. Animals were fasted $12 \mathrm{hr}$ before the experiment and anesthetized with intramuscular injection of ketamine $(20 \mathrm{mg} / \mathrm{mL})$ and thiopental intraperitonial $(20 \mathrm{mg} / \mathrm{Kg})$. They breathed spontaneously throughout the procedures. After shaving, the abdominal skin was disinfected with $70 \%$ alcohol and all procedures were performed under sterile conditions. In all rats $0.1 \mathrm{~mL}$ of $99 \mathrm{mTechnetium-}$ Etilenodicisteine (0.5 miliCurrie) was injected into the previously dissected jugular vein. After 15 minutes, the animals underwent an initial renal scintigraphy, by using the Kodak Image Station In Vivo FX (USA). The Kodak molecular imaging software v.4.0.5 was used to process the radionuclide exposure for 7 minutes. At the end of scintigraphy, the rats were transferred to the operating room. A $5 \mathrm{~cm}$ midline laparotomy was performed, the left kidney was exposed, and the renal artery was isolated and occluded with a nontraumatic microaneurism clamp for $60 \mathrm{~min}$. The right kidney was not manipulated. During the renal ischemia the abdominal incision was temporarily closed with 4-0 nylon running sutures. After 60 min of ischemia, the abdominal wall was opened again and the clamp was removed. The abdominal wound was sutured with nylon 4-0 and the animals were allowed to recover.

The sildenafil treated group rats (GS) were given $1 \mathrm{mg} / \mathrm{Kg}$ sildenafil suspension, orally via gavage, $60 \mathrm{~min}$ prior to ischemia. The control group rats (CG) were treated orally with the same volume of saline solution $0.9 \%$. About six rats of each group were re-anesthetized after $24 \mathrm{~h}$ and seven days of reperfusion, and a new scintigraphy was performed. After that, the rats were euthanased with an overdose of intracardiac thiopental (100mg/kg).

\section{Scintigraphic examination}

The scintigraphic images were evaluated by comparing the differential function between the right and left kidney, after $24 \mathrm{~h}$ and seven days of reperfusion, in all rats. Image analysis was performed using the Kodak molecular imaging software, generating automatic regions of interest (auto-ROIs) from both right and left kidneys. The sum of intensity in pixels defined the differential function in each kidney. The designs resulting from auto-ROIs were performed by the same examiner, in order to exclude the inter-observer error.

\section{Histopathology}

The kidneys were removed and paraffin sections of kidneys fixed in $10 \%$ neutral buffered formalin were stained with hematoxylin and eosin. Histological changes were examined by light microscopy in a blinded fashion, evaluated and scored. For purposes of quantitative analysis of histological pattern, tissue changes after I/R were ranked by scores that ranged from 0 to 4 , as shown in Table 1.

TABLE 1 - Scores used for histopathological evaluation

\begin{tabular}{cc}
\hline SCORES & HISTOPATOLOGICAL PATTERN \\
\hline 0 & Normal \\
0.5 & Small focal injuried areas \\
1 & $<10 \%$ of cortical injuried zone \\
2 & 10 to $25 \%$ of cortical injuried zone \\
3 & 25 to $75 \%$ of cortical injuried zone \\
4 & $>75 \%$ injuried \\
\hline
\end{tabular}

The scores were applied to microscopic changes consistent with tubular necrosis: dilation of tubular lumen, tubular cell vacuolization, intratubular cylinders, tubular cell necrosis and interstitial fibrosis. Each kidney had its corresponding scores determined by two observers. 


\section{Statistics}

The experiment was completely randomized, with statistical analysis done by Student t test for the scintigraphic data and the Mann-Whitney test for histological data. The level of significance for the tests was 5\% (CI 95\%), and $\mathrm{p}<0.05$ was considered significant.

\section{Results}

\section{Scintigrafic results}

In the right kidney we did not observe changes in scintigraphic images obtained before I/R, after 24 hours and after seven days of I/R. However, observing the left kidneys of the control group rats, the images of seven days after I/R detected a functional deficit whose scintigraphic pattern is consistent with acute tubular necrosis (Figure 1), compared to their baseline (initial) scintigraphic study (Figure 2). The difference was significant $(\mathrm{p}=0.01)$. The data from scintigraphic images are expressed by pixels of differential function, as shown in Table 2.

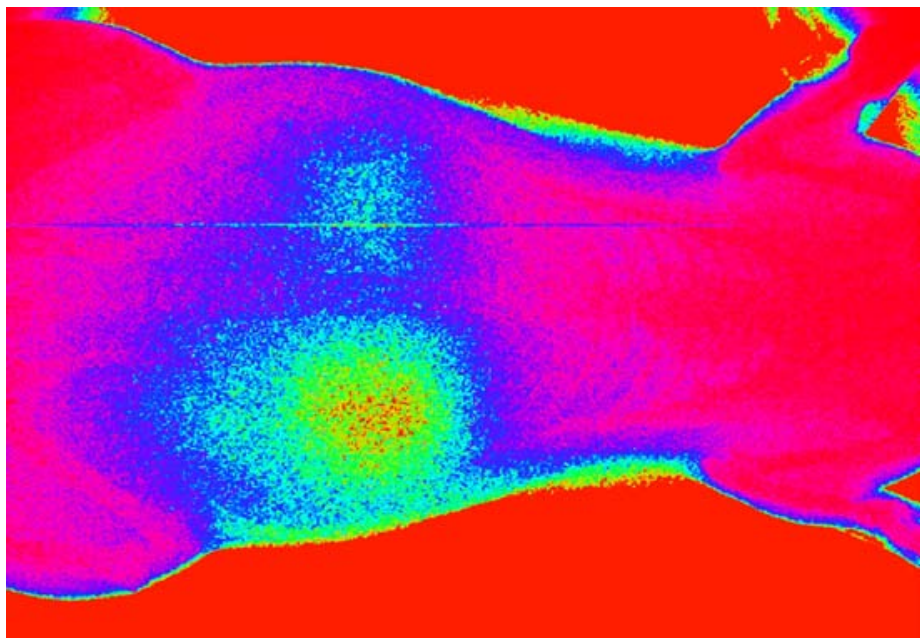

FIGURE 1 - Scintigraphic image after seven days of I/R, from control group rat (without the use of sildenafil), showing a large reduction of the radiotracer uptake in the left kidney (functional deficit), when compared with the right kidney.

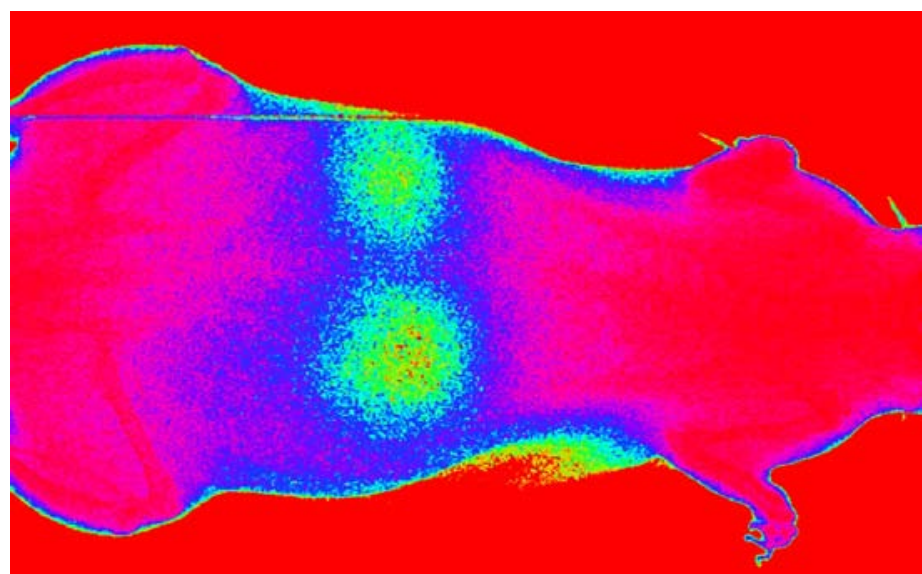

FIGURE 2 - Baseline (initial) scintigraphic image, captured before I/R, from control group rat. No difference in the radiotracer uptake was observed comparing the right and left kidneys.
In the experimental SG group, it was found that the use of sildenafil resulted in a protecting effect, and no change in renal function was observed after I/R. Table 2 shows that no significant difference between the values of differential function of the left kidney was detected, comparing data before ischemia and after 24 hours reperfusion $(\mathrm{p}=0.787)$ and 7 days after $\mathrm{I} / \mathrm{R}(\mathrm{p}=0.343)$.

TABLE 2 - Descriptive data (pixels) of differential renal function defined by scintigraphy, using Kodak Molecular Imaging Software

\begin{tabular}{l|cc|c}
\hline \multirow{2}{*}{ Left kidney } & \multicolumn{2}{|c|}{ Renal function (\%) } & \multirow{2}{*}{ p-valor ${ }^{(1)}$} \\
\cline { 2 - 3 } & Baseline & After I/R & \\
\hline Control 24 hours & $48.0 \pm 2.0$ & $47.0 \pm 5.0$ & 0.761 \\
\hline Control 7 days & $49.0 \pm 2.0$ & $46.0 \pm 3.0$ & 0.010 \\
\hline Sildenafil 24 hours & $50.0 \pm 2.0$ & $49.0 \pm 2.0$ & 0.787 \\
\hline Sildenafil 7 days & $49.0 \pm 1.3$ & $47.0 \pm 3.0$ & 0.343 \\
\hline
\end{tabular}

Mean \pm Standard Deviation

1. P-valor; analysis by Student t test.

2. I/R, ischemia/reperfusion

\section{Histopathologic results}

Renal I/R injury caused marked alterations in histology of the left kidneys compared with right kidneys, not subjected to ischemia. At 24h postreperfusion the left kidney tissue from control rats showed significant changes, when compared to sildenafil treated animals. Parallel to the marked deterioration of differential renal function of control group rats, the left kidneys harvested from these animals (24h post-ischemia) were significantly more affected by cellular necrosis (CN) when compared with the left kidney of rats treated with sildenafil $(p=0.04)$. However, no difference was observed between the two groups, when the cell vacuolation $(\mathrm{CV})$ and intratubular cylinders (IC) in renal tissue were examined $(\mathrm{p}=0.28$ and $\mathrm{p}=0.72$ respectively). Dilatation of tubular lumen (DTL) was significantly more frequent in the sildenafil group rats compared with controls $(\mathrm{p}=0.02)$. These data are summarized in Table 3 .

TABLE 3 - Data set and its statistical test scores for the histopathologic changes in the left kidney, comparing the control and sildenafil groups, after 24 hours of I/R observation

\begin{tabular}{l|cc|c}
\hline \multirow{2}{*}{$\begin{array}{l}\text { Histomorfometric } \\
\text { parameter }\end{array}$} & \multicolumn{2}{|c|}{ Left kidney } & \multirow{2}{*}{ P-valor $^{*}$} \\
\cline { 2 - 3 } & Control & Sildenafil & \\
\hline DTL & $0.75 \pm 1.04$ & $2.20 \pm 0.84$ & 0.02 \\
CV & $2.31 \pm 1.39$ & $1.80 \pm 0.45$ & 0.28 \\
IC & $1.88 \pm 1.36$ & $2.20 \pm 0.84$ & 0.72 \\
CN & $1.31 \pm 1.41$ & $0.20 \pm 0.27$ & 0.04 \\
\hline
\end{tabular}

Mean \pm Standard Deviation; * P-valor, Mann-Whitney test, significance 5\%

DTL - Dilation of Tubular Lumen; CV - Cellular Vacuolization; IC Intra-tubular Cylinder; CN - Cellular Necrosis 
Histopathological images of the left kidney can be observed in Figure 3 (control rat), where there is higher presence of cellular necrosis than in figure 4, from rat treated with sildenafil (24h after I/R).

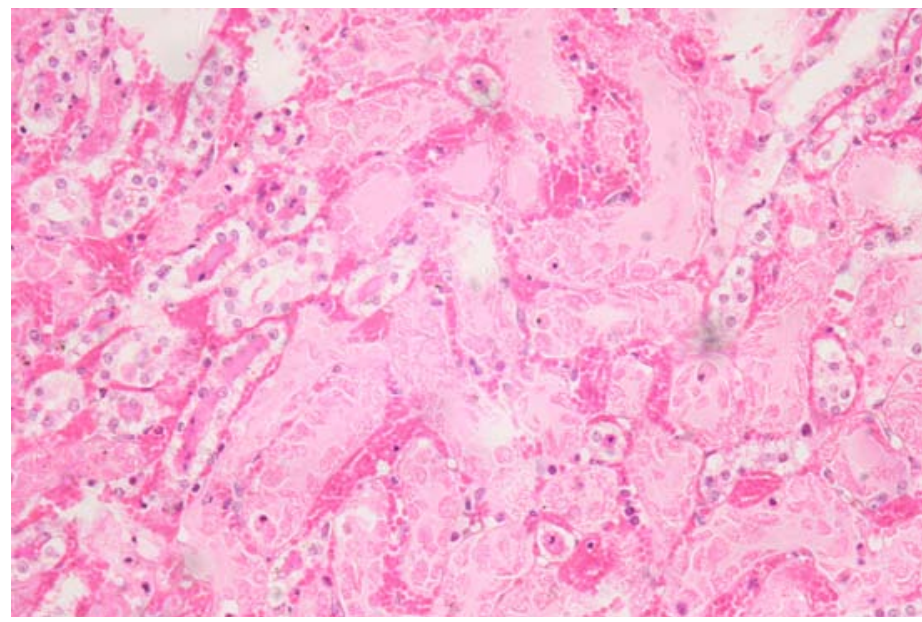

FIGURE 3 - Photomicrography of kidney of rat from the control group (24 h after I/R), showing cell necrosis. Hematoxylin-eosin stained section, magnification $200 x$

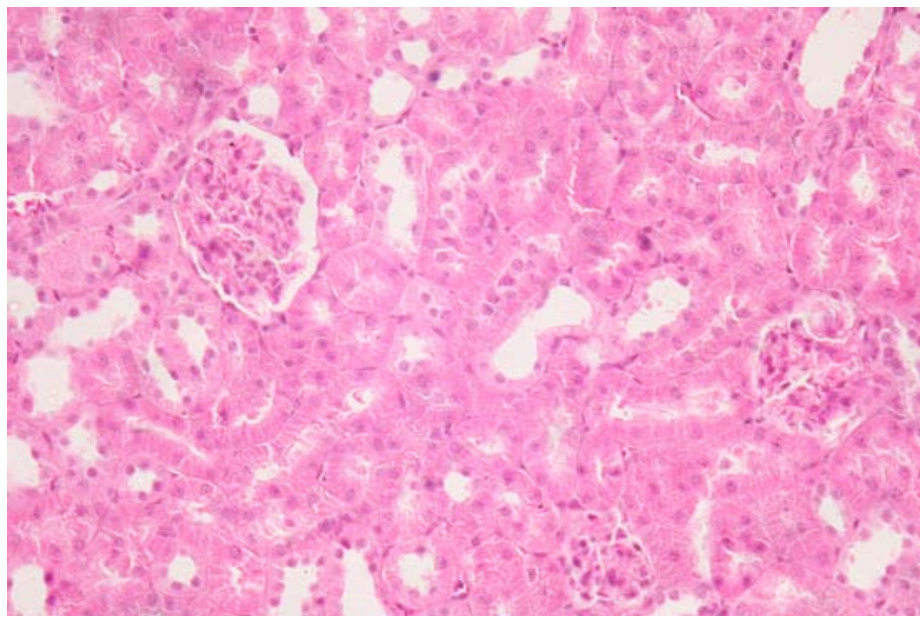

FIGURE 4 - Photomicrograph of kidney from a sildenafil group rat, showing minor cellular necrosis and intense dilation of tubular lumen. Hematoxylin-eosin stained section, magnification 200x

After seven days of the I/R event, we observed no significant differences in histopathological changes between the two groups, as shown in Table 4.
TABLE 4 - Scores Data on the histopathologic changes in the left kidney, comparing the control and sildenafil groups, after seven days of $\mathrm{I} / \mathrm{R}$

\begin{tabular}{l|cc|c}
\hline \multirow{2}{*}{$\begin{array}{l}\text { Histomorfometric } \\
\text { Parameter }\end{array}$} & \multicolumn{2}{|c|}{ Left kidney } & \multirow{2}{*}{ P-valor } \\
\cline { 2 - 3 } & Control & Sildenafil & \\
\hline DTL & $0.95 \pm 0.69$ & $1.86 \pm 0.90$ & 0.055 \\
CV & $1.15 \pm 0.78$ & $1.43 \pm 0.53$ & 0.229 \\
IC & $0.30 \pm 0.35$ & $0.71 \pm 0.57$ & 0.108 \\
CN & $0.05 \pm 0.16$ & $0.00 \pm 0.00$ & 0.739 \\
\hline
\end{tabular}

Mean \pm Standard Deviation; * P-valor, Mann-Whitney test, significance 5\%

DTL - Dilatation of Tubular Lumen; CV -Cellular Vacuolization; IC Intra-tubular Cylinder; CN - Cellular Necrosis

\section{Discussion}

All organs to be transplanted remain in a period of cold preservation before being implanted in recipients. In these cases, the ischemia and reperfusion organ injury (I/R) is a complex process involving the period of anoxia during cold preservation, followed by reperfusion, whose injury depends on the period after implantation, occurring in all organs transplanted and is directly related to the length of ischemia time ${ }^{1,4}$. The interruption of renal blood flow during clamping of the vascular pedicle is required during partial nephrectomy, especially in tumors deeply located into the renal parenchyma. The remnant kidney suffers the consequences of the I/R process, and the most important factor in the return of organ function appears to be the time of ischemia. It has been demonstrated in experimental studies that the maximum duration of warm ischemia, associated with complete recovery of renal function is 30 minutes, but some authors postulate that this time can be extended up to 90 minutes $^{9-11}$. In the present work the time of renal ischemia in the experimental model was 60 minutes.

Several studies have been conducted to explain the pathophysiology of renal $\mathrm{I} / \mathrm{R}$, trying to find drugs and measures that reduce their effects. Among them, nitric oxide (NO), a vasodilator that helps to decrease the expression and activity of endothelin in vascular endothelium, may be protective against ischemic renal injury. With endothelial injury, production of NO by the endothelial nitric oxide synthetase is inhibited. It has been demonstrated that warm ischemia leads to increased renal vascular resistance, probably caused by a loss on the ability of vascular endothelium to produce and release NO, or by an imbalance between production of NO and endothelin-1, which is essential to the vascular function on regulating of organ perfusion $^{6,13}$.

Experimental studies with NO and carbon monoxide have shown a protective effect against injury after $I / R^{5,6}$. An experimentally study described the use of sodium nitroprusside 
(a NO donor) in kidneys isolated from animals subjected to warm ischemia and reperfusion. It was demonstrated higher renal blood flow and lower renal vascular resistance, comparing with controls ${ }^{5}$.

Öztürk et al. ${ }^{6}$ studied the molsidomine in the process of $\mathrm{I} / \mathrm{R}$. The molsidomine is a potent vasodilator that is widely used as antianginous, relaxing the smooth muscle by stimulating guanylate cyclase, increasing the levels of cyclic guanosine monophosphate (cGMP). The objective of their study was to investigate the protective effect of molsidomine on renal function and histomorphometry during the first week after I/R. A rat model of right nephrectomy and occlusion of the left renal artery for 1 hour was used. All rats had blood urea and creatinine dosed daily and renal histological analysis was done on seventh day. Molsidomine group rats had better recovery of urea and creatinine, a better survival and lesser degrees of kidney injury when compared with the control group ${ }^{6}$. This experimental design was similar to that used in our work, except the right nefrectomy, not performed in our rats.

The phosphodiesterase inhibitors are a class of vasoactive drugs that have been developed for the treatment of erectile dysfunction. The mechanism of action involves inhibition of the enzyme phosphodiesterase-5 (PDE-5), resulting in increased cGMP and relaxation of smooth muscles in the penis. There are 11 fosfosdiesterases families identified in mammals. Immunohistochemical studies have demonstrated the presence of PDE-5 in vascular smooth muscle, in bronchial tissues and platelets $^{14-16}$. Over the past 10 years, there has been considerable interest in investigating the role of sildenafil in protection against injury by I/R in animal models. It was shown that sildenafil induces protective effect in myocardium ${ }^{21}$. It is possible that the vasodilating action of sildenafil contributes to the release of endogenous mediators, such as adenosine and bradykinin from endothelial cells, which triggers a cascade resulting in phosphorylation of nitric oxide syntethase and the release of $\mathrm{NO}^{17}$. This knowledge stimulated a research field for the use of inhibitors of phosphodiesterases in organs injuries caused by I/R. Some of the few experimental studies with the use of sildenafil as a protector against kidney ischemia were made by LledoGarcia et $a l .{ }^{7,8}$, who used pigs subjected to left nephrectomy and auto-transplantation of the right kidney after 45 minutes of normothermic ischemia. The results demonstrated a better hemodynamic pattern (increased blood flow and lower renal vascular resistance), favorable histology and a higher concentration of serum NO in the animals treated with sildenafil than in controls ${ }^{7,8}$.

The design of the present experiment was originally used by Araújo et al. ${ }^{18}$ who analyzed, by scintigraphy and histopathology, the action of chlorpromazine on renal normothermic ischemia. In both the work of Araujo et al. ${ }^{18}$, as in our experiment, the right kidney was preserved in all animals. So, the systemic reactions such as hypotension, hypovolemia, heart failure and nephrotoxicity could also be evident in the right kidney. Therefore, only those animals with histologically preserved right kidney remained in the protocol. The maintenance of the contralateral kidney tends to isolate the pharmacological effect of the experimental drug $^{18}$.
In this study the administration of sildenafil one hour before renal ischemia was based on experimental models of myocardic ischemia ${ }^{17,21}$. The dose of sildenafil $(1 \mathrm{mg} / \mathrm{kg})$ orally followed the model used by Lledo-Garcia et al. ${ }^{7,8}$, who found effective plasma levels ${ }^{7,8}$. We used a sildenafil suspension, but we have used successfully microemulsion ${ }^{23}$ in other experimental models ${ }^{24,25}$. In our experiment we observed less functional and histopathological changing in the left kidney of the sildenafil group rats, when compared to the left kidney of the control group, meaning a protective effect of the drug against renal I/R.

As right nephrectomy was not performed, the renal function was not measured by urea and creatinine dosage. Renal function was measured with radioisotope renogram, the method of choice for evaluating the differential function of each kidney. The 99m-technetium-mertiatide, whose chemical nomination is mercapto-acetyl-triglycine (99mTc-MAG3) is the radiopharmaceutical most widely used in studies of the differential renal function ${ }^{22}$. However, in this study we used the 99m-Technetium-ethylenedicysteine (99mTc-EC), because the 99mTc-MAG3 is not currently available in the Brazilian market. 99mTc-EC was described and introduced in nuclear medicine by Verbrugggen et al. ${ }^{20}$ in 1990 and it has an effect comparable to $99 \mathrm{mTc}-\mathrm{MAG}^{19}$. In our experiment, we used the Image Station In Vivo FX, whose scintigraphic imaging were captured by using the radioisotope phosphor screen, which converts high-energy beta particles into light (photons). The light was captured and processed into images and measured in pixels. This technique differs from that used by Araújo et al. ${ }^{18}$.

In the histopathological evaluation it was observed statistically significant difference in the scores of cell necrosis only in the left kidneys of rats examined 24 hours after I/R. In the samples of rats examined seven days after $I / R$, the histopathologic findings showed no significant differences between sildenafil and control groups, probably because of cellular recovery of kidneys 7 days after I/R. The intense tubular dilation in kidneys of sildenafil treated rats has proved to be relevant. Despite the dilation of tubular lumen being a histomorphometric characterization of tubular lesions, it can be explained by the vasodilator and natriuretic effect of sildenafil. Considering the methodology of this study, the above results and the literature collected data, sildenafil had a positive effect on the preservation of cellular function, allowing better recovery as well as protection of renal tissue exposed to I/R.

\section{Conclusion}

The experimental pretreatment with sildenafil resulted in reduced cellular damage due to renal I/R, evaluated by scintigraphy and histopathology. Further investigations are needed to establish the feasibility and efficacy of sildenafil in clinical I/R settings.

\section{References}

1. Foley DP, Chari RS. Ischemia-reperfusion injury in transplantation: novel mechanisms and protective strategies. Transplant Rev. 2007;21:43-53. 
2. Desai MM, Gill IS, Ramani AP, Spaliviero M, Rybichi L, Kaouk JH. The impact of warm ischemia on renal function after laparoscopic partial nephrectomy. BJU Int. 2005;95:377-83.

3. Riggs SB, LaRochelle JC, Belldegrun AS. Partial nephrectomy: a contemporary review regarding outcomes and different techniques. Cancer J. 2008;14:302-7.

4. Derweesh IH, Novick AC. Mechanisms of renal ischaemic injury and their clinical impact. BJU Int. 2005;95:948-50.

5. Hosgood SA, Bagul A, Kaushik M, Rimoldi J, Gadepalli RS, Nicholson ML. Application of nitric oxide and carbon monoxide in a model of renal preservation. Br J Surg. 2008;95:1060-7.

6. Öztürk H, Aldemir M, Büyükbayram H, Dokucu A, Otçu S. The effects of the nitric oxide donor molsidomine prevent in warm ischemia-reperfusion injury of the rat renal - A functional and histophatological study. Int Urol Nephrol. 2001;32:601-7.

7. Lledo-Garcia E, Rodriguez-Martinez D, Cabello-Benavente R, MoncadaIribarren I, Tejedor-Jorge A, Dulin E, Hernandez-Fernandez C, Del CanizoLopez JF. Sildenafil improves immediate posttransplant parameters in warm-ischemic kidney transplants. Experimental study. Transplant Proc. 2007;39:1354-6.

8. Lledo-García E, Rodríguez Martínez D, Cabello Benavente R, Dulín E, García Bordas J, Fernández Álvarez E, Hernández-Fernández C, Del Canizo Lopez JF. Precondicionamiento farmacológico con sildenafilo del riñón con isquemia normotérmica. Actas Urol Esp. 2008;32:67-74.

9. Humphreys MR, Castle EP, Lohse CM, Sebo TJ, Leslie KO, Andrews $P E$. Renal ischemia time in laparoscopic surgery: an experimental study in a porcine model. Int J Urol. 2009;16:105-9.

10. Baldwin DD, Maynes LJ, Berger KA, Desai PJ, Zuppan CW, Zimmerman GJ, Winkielman AM, Sterling TH, Tsai CK, Ruckle HC. Laparoscopic warm renal ischemia in the solitary porcine kidney model. Urology. 2004;64:592-7.

11. Orvieto MA, Tolhurst SR, Chuang MS, Lyon MB, Ritch CR, Rapp $\mathrm{DE}$, Shalhav AL. Defining maximal renal tolerance to warm ischemia in porcine laparoscopic and open surgery model. Urology. 2005;66:1111-5. 12. Simmons MN, Schreiber MJ, Gill IS. Surgical renal ischemia: a contemporary overview. J Urol. 2008;180:19-30.

13. Jeong GY, Chung KY, Lee WJ, Kim YS, Sung SH. The effect of a nitric oxide donor on endogenous endothelin-1 expression in renal ischemia-reperfusion injury. Transplant Proc. 2004;36:1943-5.
14. Beavo JA. Nucleotide phosphodiesterases: functional implications of multiple isoforms. Physiol Rev. 1995;75:725-43.

15. Shin HS, Bae SK, Lee MG. Pharmacokinetics of sildenafil after intravenous and oral administration in rats: Hepatic and intestinal first-pass effects. Int J Pharm. 2006;320:64-70.

16. Gupta M, Kovar A, Meibohm B. The clinical pharmacokinetics of phosphodiesterase-5 inhibitors for erectile dysfunction. J Clin Pharmacol. 2005;45:987-1003.

17. Kukreja RC, Salloum F, Das A, Ockaili R, Yin C, Bremer YA, Fisher PW, Wittkamp M, Hawkins J, Chou E, Kukreja AK, Wang X, Marwaha VR, Xi L. Pharmacological preconditioning with sildenafil: basic mechanisms and clinical implications. Vasc Pharmacol. 2005;42:219-32. 18. Araujo WM, Tucci Jr S, Costa, RS, Ferreira RA, Pozza ML, Mazzetto AS, Alves P, Cologna AJ, Martins ACP. Animal model of renal ischemic injury, and chlorpromazine protector effect, evaluated by Tc99m-MAG3 dynamic renal scan. Acta Cir Bras. 2002;17:15-9.

19. Mooran JK. Technetium-99m-EC and other potential new agents in renal nuclear medicine. Semin Nucl Med. 1999;29:91-101.

20. Verbruggen AM, Nosco DL, Van Nerom CG, Bormans GM, Adnaens PJ, De Roo MJ. Technetium-99m-L, L-ethylenedicysteine: a renal imaging agent. i. labeling and evaluation in animals. J Nucl Med. 1992;33:551-7.

21. Bremer YA, Salloum F, Ockaili R, Chou E, Moskowitz WB, Kukreja RC. Sildenafil citrate (viagra) induces cardioprotective effects after ischemia/reperfusion injury in infant rabbits. Pediatr Res. 2005;57:22-7. 22. Caglar M, Gedik GK, Karabulut E. Differential renal function estimation by dynamic renal scintigraphy: influence of background definition and radiopharmaceutical. Nucl Med Commun. 2008;29:1002-5.

23. Formiga FR, Fonseca IAA, Souza KB, Silva AKA, Macedo JPF, Araújo IB, Soares LA, Egito ES. Influence of a lipophilic drug on the stability of emulsions: an important approach on the development of lipidic carriers. Int J Pharm. 2007;344:158-60.

24. Rego ACM, Araújo Filho I, Damasceno BPGL, Egito EST, Silveira IA, Brandão-Neto J, Medeiros AC. Simvastatin improves the healing of infected skin wounds of rats. Acta Cir Bras. 2007;22(Suppl. 1):57-63.

25. Souza-Neto JL, Araújo-Filho I, Rego AC, Dominici VA, Azevedo IM, Egito EST, Brandão-Neto J, Medeiros AC. Effects of simvastatin in abdominal sepsis in rats. Acta Cir Bras. 2006;21:8-12.

\section{Correspondence:}

Aldo Cunha Medeiros

Av. Cordeiro de Faria, S/N

59010-180 Natal - RN Brasil

aldo@ufrnet.br

Conflict of interest: none Financial source: $\mathrm{CNPq}$

Received: March 23, 2010

Review: May 18, 2010

Accepted: June 16, 2010

\section{How to cite this article}

Medeiros PJ, Villarim Neto A, Lima FP, Azevedo IM, Leão LRS, Medeiros AC. Effect of sildenafil in renal ischemia/reperfusion injury in rats. Acta Cir Bras. [serial on the Internet] 2010 Nov-Dec;25(6). Available from URL: http://www.scielo.br/acb

*Color figures available from www.scielo.br/acb 